life. Environmental effects at large are only briefly treated as they emerge in the historical narrative alongside the growing environmental consciousness of the r960s and I970s. Aso's narrative also suffers from a top down perspective, and, while operating within the colonial period, mostly addresses his history through the activities of colonial officials. Whenever it is possible Aso does incorporate indigenous voices as discovered in archival records and through oral and autobiographical histories. However, the volume is largely structured around a series of "great men", mostly scientists or scholars such as Alexandre Yersin, Henry Morin, Pierre Gourrou, and Paul Mus, but also politicians such as Ngô Đình Diệm. These figures and their contributions, successful or otherwise, dominate Aso's narrative. His familiarity with their lives and work is far reaching and frequently used to illustrate fluctuating attitudes to Vietnamese rubber plantations, the indigenous population, and the French colonial project. In a sense, these characters are a means to an end, singularly towering figures through which to portray the changing landscape of Vietnam. However, an overreliance on these men distracts from the wider sociological changes taking place on a less individualistic level.

In spite of some of these flaws, Aso's text is a welcome contribution to the literature that provides a unique viewpoint on the modern history of Vietnam. Aso's multilingual scholarship opens archival and Vietnamese language materials inaccessible to some readers. The author's interviews conducted with former plantation workers are a valuable resource and an admirable addition to the source material. An excellent case is made to show that if the plantation economy was of an almost singular focus to the French colonial authorities during their tenure as the governors of Vietnam, it was of hardly less focus to those who would supplant them. Though less genuinely ecological than its title would suggest, Rubber and the Making of Vietnam is a worthwhile effort to unite sometimes disparate strands of history under a single unifying theme. Plantation agriculture for export was the dominant mode of production for an array of Southeast Asian economies for the majority of the modern period. This volume never loses sight of that dominance and is earnest in its efforts to tease out its ramifications.

\title{
Robert Keenan
}

Rural and Environmental History Department, Wageningen University Hollandseweg I, $6706 \mathrm{KN}$, Wageningen, The Netherlands

E-mail: rob.keenan@wur.nl doi:10.1017/S0020859020000425

Toshrov, Alex. Agrarianism as Modernity in 20th-Century Europe. The Golden Age of the Peasantry. Bloomsbury Academic, London 2019. viii, 23 I pp. \$103.50. (E-book: \$82.80.)

During the Cold War, peasant parties and the corresponding "ideology" of agrarianism were largely forgotten by historians and political scientists in the East and West. Communist historians considered peasant parties leftist traitors to the Marxist-Leninist cause, akin to the narodniki and Social Revolutionaries. To Anglo-Saxon historians, the peasant leaders had failed to turn their parties into viable alternatives to communist dictatorship, both in the interwar period and in the immediate postwar years. With the end of the Cold War came 
a revival of sorts for the peasant parties that had existed in almost every Eastern European country before World War II. In some cases, quite literally, with newly founded postcommunist parties brandishing old party names in, for instance, Poland or Romania. More importantly, historians became interested in the ideas of agrarianism and the parties' life stories of fusions, feuds, and splits.

Social and economic historians have demonstrated that neither the end of the second serfdom in the eighteenth and nineteenth centuries, nor the land reforms after World War I did much to improve the life of the starving villagers. Historians of ideas, however, find much to their taste in the rich supply of political ideals and visions in agrarianism. As the title suggests, the book by Alex Toshkov (Columbia University) belongs to the second category: few peasants in Bulgaria or Latvia are likely to have considered the interwar years "a golden age" in terms of economic subsistence and social stability. In his endeavour to capture "the aspirations and limitations of the golden age of the European peasantry", Toshkov takes a keen interest in agrarianism's most extreme figure, Alexandar Stamboliiski, and is determined to recover the peasantry "from the dustbin of history" (p. 5 ).

The author argues that the peasant has been relegated to this dustbin as he was considered anathema to modernity, and that decades of history writing have been unable to reverse this image of failure and doom, but for a handful of dedicated historians. Given this historiographical quagmire, his decision to use a caricature on the cover of his book that, at first sight, depicts a starving peasant and typical capitalist who turns out to be heavy-set peasantist Stamboliiski, is ill-advised. Similarly, the realization that the title "golden age" is intended as an ironic swipe at the literature that defines progress solely in terms of political success and socio-economic reform will be understood only by those who buy and actually read Toshkov's book. (As proof, I left my initial hunch on the purpose of the book in the first paragraph of this review.)

Toshkov's alternative hypothesis is the impossibility for other parties and movements in the interwar period to ignore or marginalize agrarianism. Thus, its impact has been largely implicit, subverting the strategies of others and constraining their options. Apart from decades of conflicting historiographical biases and partisanship, the multilingual, multi-archival nature of such an endeavour has been another compelling reason for historians to steer clear of agrarianism and focus on individual cases of national parties and their leaders instead. Toshkov's achievement in studying such a disparate corpus of literature in Bulgarian, Czech, English, French, Russian, Croatian, and German cannot be overestimated. This achievement is surpassed only by his relentless quest for the archives of the various movements and parties. In this respect, future historians are indebted to Toshkov for, for instance, determining once and for all that the coveted archive of the Prague-based Green International did not survive the troubles of the twentieth century.

For good reason, the author refuses to structure his study along the lines of national case studies, as they inevitably highlight national idiosyncrasies rather than common traits of peasant parties. He also turns down the option of giving centre stage to his debunking of existing historiographies on agrarianism, as he feels such a debate would produce an antithesis rather than a new synthesis. Eager to dissect various aspects, such as the consequences of the two world wars (Chapter One), Toshkov is oblivious to his readers' need for a basic factual introduction to the history of Yugoslav, Czech, and Bulgarian agrarianism as well as to the key players of the drama and its socio-economic context.

Thus, Chapter One narrates and analyses Stamboliiski's igis audience with Tsar Ferdinand. Amidst Toshkov's historical details, conceptual analyses, and historiographical excursions, the reader is very much left to their own devices to piece together the bigger 
picture. The author's ambition to escape the frame of parochial national studies and even to bring the relevance of the peasant parties home to non-East Europeanists is explicit in the Introduction. Toshkov's refusal to make any concessions to a classic book composition, alas, defeats this laudable ambition. It is implicit associations of persons and events that seem to drive the narrative forward, rather than a carefully crafted composition balancing generic trends and national specificities, a chronology of events and structural developments.

Chapter Two addresses efforts to organize the so-called Green Peasant International as a third way, in-between capitalism and communism; Chapter Three looks at the redefining of nation and citizenship by the agrarianists. Individual historical sources - be it a letter from the archives, a specific pamphlet, or a newspaper article - are used to illustrate rather than prove the author's arguments. The national issue in Stamboliiski's Bulgaria, for instance, is exemplified by analysing the plans of his Minister of Education, Omarchevski, to reform orthography and the ensuing conflict between the ministry and the University of Sofia. The conflict is obviously linked to the tension between paternalistic and populist understandings of nationalism and the underlying issue of democratization. Using such illustrative case studies, the author engages in equally thorough exchanges with other scholars' work, including Ivo Banac on (Yugoslav) nationalism studies and Partha Chatterjee on subaltern studies. The author insists that the chapters "are self-contained thematic explorations of key aspects of the interwar agrarian experience” (p. I68). Yet, without the support of a stringent narrative, all these empirical and theoretical elements fail to produce a convincing synthesis that might serve as a robust alternative to the established truisms on agrarianism.

Entitled "Drawing the Curtain", Chapter Six, too, shows a degree of regret at the historical demise of agrarianism as an intellectual and political phenomenon, as does the "golden age" in the book title. The objective of the book is restated in the Recapitulation: "This book has been about capturing the richness of the agrarian moment in a historical setting that empowered the peasant subject and mobilized that subject toward a revision and reimagination of the social field" (p. I67). Next, the author takes previous historians to task for having been dismissive of agrarianism for decades. He criticizes Richard Crampton for not recognizing agrarianism as a full-blown ideology on a par with fascism and communism, and scathes, quite unfairly, a famous, but outdated, textbook by Barbara Jelavich. ${ }^{\mathrm{I}}$ His criticism of the more generic literature on Eastern Europe - "the condescension of posterity" (p. I68) holds more than a grain of truth. Yet, doubts remain as to whether Agrarianism as Modernity is the best way to remedy this historiographic fallacy and "allow agrarianism to receive its proper due as one of the most original and significant political currents of twentieth-century Europe" (p. 73).

In sum, Agrarianism as Modernity is an extraordinary combination of disappointment and accomplishment. On the one hand, Toshkov's command of the complex literature is exemplary, as is his quest to piece together and study the relevant archival sources. On the other hand, the learning curve for the reader is extremely steep. The concise monograph reveals its insights and genius only to readers who have first familiarized themselves with the arcane history and intricate historiography around Alexandar Stamboliiski, Stjepan Radić, and Antonin Švehla. Thus, the monograph is certainly not the definitive comparative study of agrarianism in Eastern Europe. Yet, no less certain, even if this field of study

I. Barbara Jelavich, History of the Balkans (Cambridge, I983), 2 vols. 
continues to expand at its present rate, Toshkov's pointers will be considered of value in the new historiography on agrarianism for many years to come.

Wim van Meurs

Research Institute for Culture \& History

Radboud University Nijmegen Erasmusplein I, 6525 HT Nijmegen, The Netherlands

E-mail: w.v.meurs@let.ru.nl

doi:10.1017/S0020859020000437

Pagis, Julie. May '68. Shaping Political Generations. [Protest and Social Movements.] Amsterdam University Press, Amsterdam 20I8. 320 pp. Ill. $€ 105.00$

This volume reinforces the notion that the paramount French export in history has been the concept of revolution. The Great Revolution established a new calendar which created a Year One on the foundation of the First Republic in 1793 . Pagis argues that for certain individuals the events of May I 968 were their Year One, a conscious break with the past that provided new possibilities for activists. Inspired by what Pierre Bourdieu termed "the critical moment" or the "shared foundational event" (p. 2 I I) of 1968, in the I970s Pagis's parents resigned from their stable government jobs to return to the land as peasants. Their daughter became a political sociologist through meritocratic French Republican education.

Pagis's study focuses on "the family transmission of these [1968] events" (p. 28). Her perspective explores political and generational causes and consequences of participation in movements of the Sixties. Largely through interviews, she investigates hundreds of dedicated militants, disillusioned former activists, and their children, all of whom - in sharp contrast to Hervé Hamon's and Patrick Rotman's best-selling, similarly-titled but much less nuanced, Génération (1988) - never gained national reputations. Her biographical approach confirms that "it is impossible to understand what activism produces without also simultaneously studying what produces activism” (p. I 20).

Her excellent research turns up some surprising information. Forty per cent of her sample of May militants were educated by parents who were practicing Christians, usually Catholics. Their children became sympathetic to a humanist critique of capitalism and adopted varieties of Third-Worldism during the anti-Algerian and anti-Vietnam war movements. Less surprising is the over-representation in her pool of activist Jews (seventeen per cent) who were both Communist and Jewish and thus often members of doubly contested, if not persecuted, minorities. First-generation intellectuals from a working-class or peasant background often felt a certain "social illegitimacy" (p. 65), at least in the eyes of their more affluent classmates. Many ultimately became interested in Bourdieu's critical sociology and the study of social sciences in general.

During the 1968 crisis of "authority relations" (p. 78) that undermined traditional religion, morality, and education, some young men and even more women viewed themselves as "reborn" intellectually and emotionally. The ' 68 events destabilized the trajectories of these individuals who subsequently joined new social and friendship networks. The most radical wanted to disrupt social reproduction, and many came to reject the traditional family 